\title{
The Construction of the Evaluation System of College Foreign Language Teaching under the Situation of Innovation and Entrepreneurship Education
}

\author{
Yang Fen \\ School of Foreign Languages, Kunming University, Kunming 650214, China
}

Keywords: innovation and entrepreneurship; foreign language education; evaluation system; modern education; curriculum content

\begin{abstract}
With the deepening of the reform of education and teaching in colleges and universities in our country, it has become one of the most important tasks to cultivate students' innovative consciousness and entrepreneurial ability, and the innovation and entrepreneurship education has become an essential teaching content in colleges and universities. In order to improve the innovative and entrepreneurial ability of foreign language college students and improve the teaching level of innovation and entrepreneurship, the present situation of foreign language teaching in colleges and universities is analyzed. The basic framework of foreign language teaching courses based on innovation and entrepreneurship is put forward. Finally, the teaching evaluation system is put forward, which can be used for the modern foreign language teaching technology in colleges and universities. The research provides a valuable reference.
\end{abstract}

\section{Introduction}

In order to cultivate the innovative and entrepreneurial ability of foreign language majors, it is the responsibility of colleges and universities to cultivate the innovative and entrepreneurial ability of foreign language majors. In order to cultivate a comprehensive quality person with both professional knowledge and innovative entrepreneurial ability, a new foreign language teaching plan must be formulated. To bring the innovative and entrepreneurial ability of foreign language major into the teaching goal, construct the curriculum system, reform the teaching mode and teaching content, so that foreign language students can actively participate in the environment of innovative and entrepreneurial learning, and give full play to the initiative of students. In order to ensure the smooth progress of the teaching work, we need to strengthen the input from the aspects of teachers, funds and assessment, so that the innovative and entrepreneurial education can be successfully implemented in the process of foreign language teaching.

\section{The Current Situation of College Foreign Language Teaching under the Situation of Innovation and Entrepreneurship Education}

At present, in the process of foreign language teaching in Colleges and universities, especially the integration of business English Teaching for innovation and entrepreneurship education is still inadequate, students lack of English thinking ability and entrepreneurial awareness, which is not conducive to the cultivation of innovative foreign language talents. The following four aspects are mainly to analyze the present situation of foreign language teaching in Colleges and universities.

\subsection{The curriculum arrangement.}

For the innovative and entrepreneurial English teaching, although part of the course setting of business English teaching is related to innovation and entrepreneurship, it is only involved in a small part, small scope and small content, the curriculum is more specialized, but lack of practicality, lack of perfect innovation and entrepreneurial knowledge system.

\subsection{The teachers' teaching level.}

In order to achieve foreign language teaching in the environment of innovation and 
entrepreneurship, the requirements for teachers' team are higher.

In the course of teaching, most of the teachers lack the experience of innovation and entrepreneurship, although they have strong professional teaching ability, but lack of knowledge of innovation and entrepreneurship, lack of professional experience and practical experience. Therefore, in the course of teaching, teachers still focus on the teaching of theory and ignore the improvement of students' ability to practice foreign languages. The effect of innovation education is not good.

\subsection{The relationship between foreign language teaching and innovation and Entrepreneurship.}

Most schools do not know enough about innovation and entrepreneurship teaching, and think that they can have some, though there are some.

Realize the importance of innovation and entrepreneurship teaching, but the form of the course is basically in the form of lectures, and it is not very important to improve the students' innovation and entrepreneurship in the past years. In addition, some schools have not integrated the concept of innovation and entrepreneurship into the daily teaching process, but on the basis of the original teaching, the innovation and entrepreneurship course has been imposed on the basis of the original teaching, and it is not related to the professional teaching.

\subsection{The lack of the most important practical courses.}

The most important part of innovation and entrepreneurship teaching is the practice link. Under the current educational background, the curriculum foundation of foreign language is set up.

There are not too many practical links and no scientific practice courses, so it is difficult for students to improve their practical ability, which is not conducive to the cultivation of innovative entrepreneurial ability.

\section{The content of College Students' foreign language teaching under the form of innovation and Entrepreneurship Education}

In order to realize the innovation of English Teaching in the form of entrepreneurship, it needs a certain teaching course content system as a support. At present, there are still many problems in the teaching content and curriculum construction of innovative entrepreneurship at home and universities, from the division of teaching tasks to the distribution of teachers' strength, from the development of the curriculum to the management of the quality of the course. Fee is put into operation guarantee and so on. The use of foreign languages, especially in foreign languages, is more and more used by the whole country. The rational development of practical and practical courses is of great significance for improving the quality of innovation and innovation of college students. Combined with modern curriculum theory and teaching practice, the curriculum content system as shown in Figure 1 is constructed.

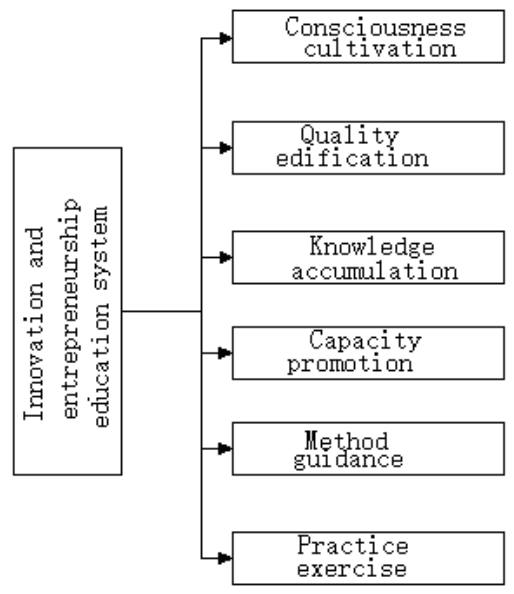

Fig.1 The curriculum content framework for college students' innovation and Entrepreneurship 
As shown in Figure 4, under the framework of College Students' innovation and entrepreneurship curriculum, it is necessary to cultivate foreign students' quality of foreign language innovation and Entrepreneurship from three aspects, including quality personality, knowledge skills and leadership ability. The quality personality of innovative entrepreneurship mainly refers to whether individuals have entrepreneurial consciousness and innovative spirit, including entrepreneurial sense of responsibility, Self confidence, self-control, optimism and other personality traits, entrepreneurial skills mainly refer to the comprehensive knowledge of entrepreneurship, including professional technology, industry knowledge, management and marketing knowledge, capital operation and so on. Leadership refers to the management and operation of enterprises after starting a business. The curriculum time system for foreign language innovation and Entrepreneurship education is arranged as Table 1. Show.

Table 1 The curriculum time system of innovation and entrepreneurship education in foreign languages

\begin{tabular}{|c|c|}
\hline Course time & Course content \\
\hline first grade & Peripheral courses \\
\hline second grade & core curriculum \\
\hline third grade & activity curriculum \\
\hline fourth grade & Practice Course \\
\hline
\end{tabular}

As shown in Table 1, in the first year of college, the students' concept of innovation and entrepreneurship is still vague. This stage is mainly to cultivate the students' awareness of innovation and entrepreneurship, gradually form the entrepreneurial personality under the influence of innovative and entrepreneurial quality, and to build up the ideal of innovation and Entrepreneurship through the expansion of students' knowledge. At the beginning of grade two, it is the core curriculum, which is the core course content. This content can be combined with the activity class to grade three, and the grade two or three encourages students to participate in more activities, such as innovation and entrepreneurship competition, face-to-face discussions, experience and academic reports of successful people. In addition to classroom learning, the students in grade three or four also need to carry out activities and practice and understand the true connotation of innovation and entrepreneurship through activities and practice.

\section{The strategy of curriculum evaluation system for foreign language majors guided by innovation and Entrepreneurship Education}

The teaching evaluation system is the vane and the baton of the foreign language innovation and entrepreneurship education curriculum construction. It is the key to determine whether the assessment of innovation and entrepreneurship education is really carried out. Only by establishing a special curriculum evaluation system with innovative and entrepreneurial characteristics can the ability of innovation and Entrepreneurship of Foreign Language Majors be really cultivated and teachers and students can be made. Actively invest in innovation and entrepreneurship teaching and learning activities. In the course of teaching evaluation, we need to combine the different characteristics of innovation and entrepreneurship teaching to formulate corresponding assessment methods.

\subsection{The assessment and evaluation of the consciousness of innovation and Entrepreneurship.}

In order to improve the innovative and entrepreneurial ability of college students, we must first establish the concept of students' innovation and entrepreneurship and cultivate their awareness of innovation and entrepreneurship. In order to encourage students to set up a concept of innovation and entrepreneurship, we should adopt the form of assessment to encourage students with a strong sense of innovation and entrepreneurship, cultivate students' interest in innovation and entrepreneurship through incentive policies, and make students actively participate in the process of innovative and entrepreneurial education. An important content of evaluation. 


\subsection{The practice of the competition.}

Innovation and entrepreneurship competition is an effective evaluation method. Through competition, it can not only test students' innovative and entrepreneurial level, but also allow students to actively participate in the process of innovation and entrepreneurship in the process of education, and improve the interest of students' innovation and entrepreneurship.

\subsection{The expert evaluation.}

Schools can employ entrepreneurs with rich experience, especially in their own businesses and have made some achievements.

Alumni are part-time teachers. Because alumni are more exemplary, their exemplary role is greater, so that they can establish students' confidence in innovation and entrepreneurship. While part-time tutors can guide students to carry out innovative and entrepreneurial practice, and give students the ability to identify and evaluate innovation and entrepreneurship, so as to improve the effect of innovative and entrepreneurial education.

\section{Conclusion}

In the context of innovation and entrepreneurship education, in order to improve the effect of foreign language teaching, the current situation of foreign language teaching is analyzed, and the curriculum content system based on innovation and entrepreneurship is put forward. On the one hand, foreign language teaching needs to be rebuilt, and the other is the evaluation of the course content. The evaluation of foreign language teaching based on innovative entrepreneurship education should pay attention to the professional curriculum system, highlight the traditional foreign language and innovative entrepreneurship vocational training, attach importance to the cultivation of students' innovative and entrepreneurial ability, and give full name to the students' comprehensive quality, and promote the all-round development of students.

\section{References}

[1] Yang Liang. Philosophical analysis and curriculum research of innovation and entrepreneurship education [J]. Science and technology innovation guide, 2014 (16): 126-127.

[2] Cao Shengli. Innovation and entrepreneurship education calls for simulated teaching and experiential courses [J]. Experimental technology and management, 2009 (8): 1-4.

[3] Peng Wenbo, Yin Xinming, Li Guanfeng, Zhang Liuzhan, Wan freshman. Exploration and practice of the construction of curriculum system for innovation and entrepreneurship education [J]. Innovation and entrepreneurship education, 2010 (4): 55-57.

[4] Liu Dai, Chen Ying. Research on the construction of curriculum system of innovation and Entrepreneurship Education -- Taking Shaoguan University as an example [J].

Journal of Shaoguan University: Social Sciences Edition, 2013 (9): 180-182.

[5] Xiao Juan. On the establishment of a curriculum system for innovation and entrepreneurship education in Colleges and universities [J]. Heihe journal, 2012 (8):152-153.

[6] Xu Xiaohua, Zhang Ge. University innovation and entrepreneurship education and curriculum system construction [J]. China electronic education, 2012 (1): 19-21.

[7] Zhong Zhi Xi. Reflections on the curriculum construction of innovation and entrepreneurship education in Colleges and universities, [J]. Theory, 2012 (30): 168-169.

[8] Zhou Wei, Huang Xiangfang. Research on the curriculum system of innovation and entrepreneurship education in Universities [J]. Cooperative economy and technology, 2012 (8): 92-93.

[9] Jiang Miao Li. China's College English teaching should be developed: to commemorate the 
reform and opening up 30th anniversary [J]. Foreign language circles, 2008, (5): 5 - 17.

[10] Jin Yan. Brief analysis of the teaching evaluation function of standardized language testing [J]. Foreign language testing and teaching, 2011, (1): 26-34, 42.

[11] Liu Guiqin. Attaches great importance to the reform of College English teaching and tries to improve the quality of College English Teaching [J]. Foreign language teaching and research, 2012, (2): 279 - 282.

[12] Tang Xiongying. Four, six level examination and College English curriculum evaluation [J]. Foreign language teaching, 2005, (1): 56 - 59.

[13] Wang Shouren, Wang Haixiao. Investigation of the present situation of English Teaching in universities and colleges in China and the direction of College English teaching reform and development [J]. Chinese foreign languages, 2011, (5): 6-13, 19.

[14] Mao Guotao. Analysis on the construction of $1+\mathrm{N}$ curriculum system of innovation and entrepreneurship education [J]. Journal of Nanchang Education College, 2011 (5): 55-57.

[15] Chang Guoliang. Thinking on the construction of the curriculum system of innovation and Entrepreneurship Education under the view of integration -- Taking the subject of University pedagogy in Heilongjiang Province as an example [J]. To continue the education research, 2013 (12): 111-112.

[16] Huang Jilei, Li Jun, Liu Chunbin. The construction and reality of the innovation and entrepreneurship education curriculum system under the "three yuan education mode" Practice [J]. today's wealth, 2011 (11): 217-218. 